\title{
SOURCES OF CHINESE OBLIGATION LAW
}

\author{
WiLLIAM JONES*
}

\section{INTRODUCTION}

Law in China is in a state of great flux at the present time. A large number of statutes dealing with everything from patent law to bankruptcies have been enacted, ${ }^{1}$ and the flow continues. The subject of law is prominent in the press. $^{2}$ Officials at all levels are required to take short courses in it. Formal legal studies have increased in the universities. All this activity contrasts markedly with the situation just prior to the Third Plenum in 1978. At that time, there were almost no law students. Statutes were few. The hostility to law that characterized the Cultural Revolution was still in evidence. As a matter of fact, though carried to extremes during the Cultural Revolution, this hostile attitude has been characteristic of the People's Republic of China since its beginnings. ${ }^{3}$ For that matter, law, as we understand the term, has played a minor role in Chinese history. ${ }^{4}$ Actually, China is adopting not just a system of law, but a system of Western law. In other words, it is adopting a system that is foreign both to its tradition, and to the principles that have supposedly served as the basis for its society since the founding of the People's Republic of China in 1949. A key element in this process was the enactment in April

Copyright $\odot 1989$ by Law and Contemporary Problems

* Professor of Law, Washington University School of Law, St. Louis.

1. The flood seems to have begun with the enactment by the National People's Congress on July 1, 1979, of seven statutes: the Criminal Code; the Criminal Procedure Code; the Election Law; the Organic Law of the Local People's Congress; the Organic Law of the People's Courts; the Organic Law of the People's Procuratorate; the Joint Venture Law. See S. Leng \& H. Chiv, Criminal Justice in Post-Mao China 304 (1984). The patent law was enacted on March 12, 1984. A translation appears in China Laws for Foreign Business (CCH) \& 11-600 [hereinafter CCH-China]. The bankruptcy law was enacted on Dec. 2, 1986. See CCH-China \$ 13-522.

2. See, e.g., Legal Knowledge Spread Nation-wide, China Daily, Apr. 26, 1986, at 3.

3. The principal evidence for this statement is the condition of "law" and lawyers in the People's Republic of China. Thus, it is said that as of the beginning of the Cultural Revolution, when all law schools were closed, 19,000 lawyers had been trained since Liberation. S. Lenc \& H. ChIU, supra note 1 , at 47 . That comes to a little over 1000 per year-not exactly a flood in the most populous nation in the world. Actually, most of the university law schools were closed in the late 1950 's. In a speech before the Party Congress in 1956, a leading member who had had legal training in the Soviet Union urged the development of a legal system. He implied that many comrades did not value such a system, and did not observe what laws there were. Dong. The Legal System of China (speech delivered before the Eighth Congress of the Communist Party of China on Sept. 20, 1956), translated in Current Background, No. 420 (Oct. 16, 1956). See also V. Li, LaW Without Lawyers (1977).

4. See Jones, Studying the Ch'ing Code, the Ta Ch'ing Lü Li, 22 Ам. J. Coмp. L. 330 (1974). 
1986 of the General Principles of Civil Law, which took effect on January 1, $1987 . .^{5}$

This statute-the General Principles of Civil Law-is particularly important because of the central position that civil law (and hence a civil code, if there is one) occupies in Western law. When it is said that Western law is based on Roman law, that is really a reference to Roman civil law. It is the body of law that was developed in Rome to deal with the private relations of Roman citizens among themselves that has served as the basis of legal education and as the conceptual structure of European law since the "revival" of Roman law in the eleventh century. ${ }^{6}$ Civil law is still what most law students study first, and its influence is pervasive. ${ }^{7}$ When a non-Western country adopts a civil code based on Roman law, it announces its intention, whether it realizes this or not, to adopt a completely new conceptual framework for its legal system.

In its German form-perhaps the most influential in the present era ${ }^{8}$-this body of law provides a particular model of the legal universe. In this universe, a "person"- not a human being, but a figure for the bearer of rightsacquires "rights" from another person by means of "juristic acts" which in turn are based on "declarations of intention." 9 This is a very individualistic world. The society envisaged by the model is one in which all activity is governed by the decisions of individuals. Such a society is not the one contemplated by the model of either traditional Chinese society or of the People's Republic of China. In the latter, significant decisions have normally been made by the Party leadership-in theory after getting input from the laboring masses. But regardless of where the ideas came from, the Party leadership made decisions on everything from the crops that were to be sown ${ }^{10}$ to the sex life of the citizens. ${ }^{11}$

Does the enactment of a German-style civil code mean that this situation has changed? Not necessarily-the Soviet Union has had German-style civil codes for over sixty years. ${ }^{12}$ It is quite possible that the promulgation of the

5. There are several translations. My own is in 13 Rev. Socialist L. 357 (1987).

6. That is, after all, what the Corpus Juris contains.

7. This includes American law students who still begin with contracts, torts, and property, although they do not normally consider Roman law in any direct way.

8. The German Code, which went into effect on Jan. 2, 1900, was the principal influence on the codes of Japan and pre-Liberation China, and quite influential in Switzerland and Turkey. For that matter, it was influential in the Soviet Union. See infra note 12. Perhaps more important is the influence of German legal thinking - the German technique of legal analysis-in other legal systems even where the Code was not adopted. See J. Merriman \& S. Clark, Comparative. Law 243-44 (1978).

9. See W. Flume, Das Rechtsgeschaeft 35 (1965): "The concepts 'juristic act' and 'declaration of intention' are often used synonymously." One possible difference arises out of the fact that a juristic act can result from several declarations of intention-a contract, for example. Id. at 26.

10. This was usually done in indirect ways by setting prices or subsidizing fertilizer, though with some direct pressure as well. For the efforts in $\mathbf{1 9 8 6}$ to increase grain production, see FAR EASTERN ECON. Rev. 78 (Mar. 18, 1987).

11. To take only the most recent example, the one child policy. See Family Planning Improves, 29 Beijing Rev. 4 (1986); S. Mosher, Broken Earth 224-61 (1983).

12. The first Soviet Civil Code was enacted in the Russian Soviet Republic (RSFSR) in I922. Its structure "followed the Pandectist system. ..." Ioffe, Civil Law, in ENCYclopedia Of Soviet Law 114,115 (F. Feldbrugge, G. Van Den Berg \& W. Simon eds. 1985). 
new Civil Code will prove to have been, in practical effect, a non-event. However, there are some peculiar features to the situation in China. First, the Chinese Civil Code is being enacted as a part of a movement that is designed to bring about radical changes in the structure of Chinese society. The aim of the changes is to bring about the "Four Modernizations"- the modernization of industry, agriculture, defense, and science and technology. ${ }^{13}$ This amounts to nothing less than rapid industrialization. The principal technique being used may be described as the individual responsibility system.

In the case of agriculture, where it began, the individual responsibility system means, in effect, that the ownership of agricultural land has been transferred from the state or collective to individual farmers or farm families. ${ }^{14}$ The Chinese will not admit this publicly. Rather, they say that the farmers do not "own" the land; the farmers merely lease it or hold it under some other form of contract. Of course in Anglo-American law, a lease is a form of conveyance of ownership as opposed to being a type of contract as it is in Roman law. ${ }^{15}$ But apart from this, while there are certainly restrictions on the ownership rights of the farmers, it is equally certain that the farmers have property rights as these are defined by the Restatement of Property. ${ }^{16}$ The farmers must meet certain state quotas, but they are free to use their land otherwise pretty much as they please, and to dispose of its produce as they

13. The importance of the Four Modernizations is shown by, among other things, the way they are referred to in the Preamble to the 1982 Constitution:

The basic task of the nation in the years to come is to concentrate its effort on socialist modernization. Under the leadership of the Communist Party of China and the guidance of Marxism-Leninism and Mao Zedong Thought, the Chinese people of all nationalities will continue to adhere to the people's democratic dictatorship and follow the socialist road, steadily improve socialist institutions, develop socialist democracy, improve the socialist legal system and work hard and self-reliantly to modernize industry, agriculture, national defense, and science and technology step by step to turn China into a socialist country with a high level of culture and democracy.

14. For a description, see Kueh, The Economics of Land Reform in China, China Q. 122 (No. 101, 1985).

15. All civil codes known to me based on Roman law treat leases as contracts. See, e.g., CoDE Civil [C. Crv.], arts. 1708-1831 (Fr.). The Roman law contract of hire (locatio conductio) included leases. B. Nicholas, An Introduction to Roman Law 182 (1962).

16. The following extracts summarize the position of the Restatement:

Introductory Note:. . .

The word property is used in this Restatement to denote legal relations between persons with respect to a thing. ...

Section 5. The word "interest" is used in this Restatement both generically to include varying aggregates of rights, privileges, powers and immunities and distributively to mean any one of them.

Comment e. Complete property. The totality of these rights, privileges, powers and immunities which it is legally possible for a person to have with regard to a given piece of land, or with regard to a thing other than land, that are other than those which all other members of society have as such, constitutes complete property in such land or thing other than land. ...

Section 10. Owner. The word "owner," as it is used in this Restatement, means the person who has one or more interests.

Restatement of Property ch. I introductory note, $\$ 5$ \& comment e, $\S 10$ (1936). 
wish. In other words, individuals can engage in juristic acts and incur obligations as to much of the produce of the soil. These rights normally pass to their descendants.

The situation in industry and commerce is more complicated. In the first place, wholly foreign-owned enterprises are clearly independent entities that make their own decisions. ${ }^{17}$ They are, of course, subject to government control, but they are certainly not like state enterprises in a planned society. The same is true, to a degree, of Sino-foreign joint enterprises. ${ }^{18}$ However, these foreign or semi-foreign entities constitute only a very small fraction of the total. The bulk of commercial and industrial activity in China has, until recently, been carried on under the plan. ${ }^{19}$ The individual responsibility system is being applied to enterprises that have been subject to the plan, but of course it is much more difficult to do this in industry or commerce than in agriculture. A collective farm is easily divided into small plots and distributed to the farmers. With the use of a lease, it is possible to pretend that nothing much has happened to disturb the primacy of collective ownership. But what does one do with a steel mill? It cannot be divided up physically. It is possible, of course, to furnish it with a certain amount of capital and permit it to operate independently, accepting both profits and losses-the profits to go ultimately to the state. But if the purpose of individual responsibility is to release the forces of individual enterprise (or selfishness, as the founders of capitalism were quite willing to admit), ${ }^{20}$ then there has to be some way for those associated with the enterprise to share in its profits and run the risk of sharing in its losses (since the danger spurs them on). There are probably people in China who could lay their hands on very large sums of $\operatorname{cash}^{21}$ and who could, in consequence, buy enterprises. However, if major industriesthose that control "the means of production"-really get into private hands in the way farm land has, there are obviously very serious ideological problems. ${ }^{22}$ This is not to say that it cannot happen, but it has not happened

17. The Law of the People's Republic of China for Enterprises with Sole Foreign Investment was enacted on Apr. 11, 1986. A translation can be found in CCH-China $\uparrow 13.506$. Section 11.2 provides: "An enterprise with sole foreign investment shall carry out its operation and management in accordance with the approved articles of association of the enterprise and free from interference."

18. "A joint venture has the right to do business independently, within the scope of the provisions of Chinese laws, decrees. . . "Regulations for the Implementation of the Law of the People's Republic of China on Joint Ventures Using Chinese and Foreign Investment, Sept. 20, 1983. A translation is found in CCH-China I 6.550 .

19. For example, the percentages of output by various types of enterprises in 1986 were as follows: state-owned, $68.7 \%$; collectives, $29.2 \%$; private, $0.3 \%$; foreign-funded $0.4 \%$; cooperative industrial enterprises, 1.3\%. 29 BEIJING REV. 28 (1987).

20. Notably by Bernard Mandeville, who, in The FABLE of THE BeEs (I. Primer ed. 1962), praised avarice and prodigality as complementary vices that produced prosperity.

21. This is surmise on my part. A number of Chinese have close relatives in other countries who are very rich. Much of the investment by "foreigners" in China is by these overseas Chinese.

22. It would be hard to disguise the fact that this would mean that there had indeed been a return to capitalism. "It is the private ownership of capital in the hands of a class-the class of capitalists to the exclusion of the mass of the population-which is a central feature of capitalism as a mode of production." A Dictionary of Marxist Thought 64 (T. Bottomore ed. 1983). 
yet, at least not to any great extent. At present, "individual responsibility" in commerce and industry seems to be more of a slogan than a reality.

Still, the potential for independent enterprises is there, and the basic legal framework for a society composed of such entities is the Civil Code. It is drafted on the assumption that the legal universe of China consists of individual entities with wills that interact, creating and changing their own positions. But this is not the universe that actually exists in China. And as a matter of fact, the General Principles of Civil Law is not really a complete code, but only what would, in Germany, be called a "General Part."23 It includes general concepts such as the nature of the person, including capacity, and the framework for such areas as property and obligation law. In a normal code these would be followed by special parts dealing with specifics: warranties in the sale of goods, for instance. ${ }^{24}$ There would also be a commercial code covering company law, negotiable instruments, and the like. None of these exists. The chairman of the committee that supposedly drafted the Code stated to the National People's Congress, when he presented the General Principles for adoption, that it had been decided to enact the civil law in bits and pieces rather than in a comprehensive code. He mentioned the Economic Contract Law, the Foreign Economic Contract Law, the Patent Law, the Trademark Law, the Succession Law, and the Family Law as being some of the elements of civil law that were enacted separately. While other statutes might be enacted, he indicated that there would be gaps. ${ }^{25}$ Any effort to understand Chinese civil law must involve not only the General Principles but these special statutes as well. One must also try to figure out what the gaps are, what they mean, and how they are to be filled.

Wherever the relevant rules may be located, whether in the General Principles or the special statutes or regulations, if civil law of the German type is going to be used in fact, the conceptual framework for managing the new system's independent entities is obligation law: contracts, torts, and restitution. Once the decisionmaking function is shifted from the planning authority to the individual entity, the basic legal device that will be used will be a contract, not an order. When a tire factory needs rubber, it has to arrange to buy it from the best available source. It does not get a directive to the rubber factory that has been designated to supply this particular need. Similarly, the entity will be liable for injuries caused by its products or workers. Therefore, if one is to understand Chinese civil law, one of the principal questions that has to be answered is, what is Chinese obligation law?

23. For a description of the German Civil Code, including the General Part and its role, see $P$. Baehr, Grundzuege des buergerlichen Rechts 14 (5th ed. 1984). See also H. Lawson, A Common LaWyer LoOKS at THE Civil. LAW 53-54, 164-69 (1953).

24. To deal with this problem, one would have to search the General Part for basic principles of contract-for example, capacity and mistake. Somewhat more specific rules are given in the General Part of the law of obligations-for example, assignment and multiple parties. The particular rules on warranties are placed in the sub-part of the Special Part labeled sales, sections 459-93.

25. Wang Hanbin on General Principles of the Civil Code (Draft), XINHUA, Apr. 22, 1986, in British Broadcasting Corp., Summary of World Broadcasts: Part III: The Far East, FE/8239/C1/10. 
There appear to be two main problems in trying to answer this question. First, since the General Principles is admittedly incomplete, and does not have any sort of catch-all clause for applying general principles of law to all matters not covered by the Code, where is the law to be found in a formal sense? ${ }^{26}$ Second, are the civil law principles, whatever and wherever they may be, in fact controlling? For example, are the Chinese going to control the problems of defective quality of goods by means of tort and contract law, or are they going to use criminal and administrative measures? Does the manager of a factory that manufactures defective products go to jail or lose his job? These questions are not often asked. The answers are not clear. But they have to be considered if one is to understand the reality of Chinese law.

II

\section{What Is the Formal Law of Obligations in China?}

When the promulgation of a civil code was being discussed, there were two points of view as to the applicability of civil law. Some advocated "big civil law," and others advocated "small civil law." The former group believed that civil law should govern the relations between all persons (in the legal sense). The latter believed that civil law should regulate only the private affairs of individual human beings-for example, the arrangement by an elderly person to give his property to a younger person in exchange for an agreement to give support. The dispute was about whether civil law included "economic law." This is a term which is rarely used in the United States, but seems to mean the law that concerns what might be called business activities.

The form of the General Principles indicates that it is this "big civil law" group that won. The principles of the General Principles clearly apply to all relevant activities whether they are between private individuals, collective entities of various sorts, or in some instances, government agencies. The result is that the General Principles constitutes in theory the basic group of legal principles that govern Chinese society in the same way that the Code civil fulfills that role in France. In the French phrase, the General Principles is "common law" (droit commun) in the sense that it comprises the basic principles of law that are referred to when more particularized laws are silent. ${ }^{27}$ Thus, the principle of "good faith"-a translation, it seems pretty clear, of the German Treu und Glauben ${ }^{28}$-is applicable to all legal transactions

26. Compare art. 1 of the Swiss Civil Code:

The Code applies to all legal questions for which it contains a provision in its terms or its exposition. If no command can be taken from the statute, then the judge shall pronounce in accordance with the customary law, and, failing that, according to the rule which he as legislator would adopt. He should be guided therein by approved precept and principle.

27. See I G. Marty \& P. Raynaud, Droit Civil 451 (2d ed. 1972), in which, after discussing the relationship of traditional civil law to the most basic aspects of human life, the authors state: "Thus a technique has been formed that has remained the basic juristic technique and that of the common law [droit commun], which is not only used in the area of civil law itself, but in the other branches of law."

28. The phrase is in section 242 of the Buergerliches Gesetzbuch [BGB] (W. Ger.): "The obligor is bound to effect performance according to the requirements of good faith [Treu und Glauben], giving 
in China whether they are contracts, conveyances of property, or appointments of agents, and whether the parties are individuals, business organizations, sports clubs, or government departments. ${ }^{29}$

Thus, any statement on the formal statutory system of obligation law in China must begin with the General Principles. It is a very pure German-style general part of a civil code. That is, it makes almost no reference to ideology (which, to be sure, makes it a very ideological statement indeed in China), and otherwise it is virtually indistinguishable from its European models except in its brevity. The General Principles begins with the "person" who is the bearer of rights. There are two types of persons-natural ${ }^{30}$ and juristic. ${ }^{31}$ While each is, by definition, capable of bearing rights, they differ in the way they are created and dissolved, and in their capacity to take legally effective action. Hence, for natural persons, the General Principles deals with such matters as minority, ${ }^{32}$ limited mental capacity ${ }^{33}$ and guardianship, ${ }^{34}$ and declarations that a person is missing or dead. ${ }^{35}$ In a general way it indicates how juristic persons come about, ${ }^{36}$ but the details of their creation and registration are not dealt with. Those provisions undoubtedly await a company law or corporation code.

The General Principles next treats the way rights are created by means of a juristic act (Rechtsgeschaeft). That is, the "person" makes a declaration of intention to change, establish, or terminate a civil law right. As a result, property is conveyed, an offer is made, a contract is formed, a partnership is created, and so on. ${ }^{37}$ Though such acts are subject to general principles of legality and good faith, ${ }^{38}$ it is up to the parties to form their own legal universe. The German Code and its clones do not include the famous language of S.1134.1 of the French Civil Code: "Agreements that are legally formed take the place of the law [statutes] for those who have made them." This principle is, however, clearly recognized in the General Part of the

consideration to common usage." One could translate these words as honesty and trustworthiness. That translation would also serve to translate the Chinese. But "good faith" is the term used in the official translations of the Nationalist Civil Code sec. 219, where it is rendered as "honesty and good faith."

29. Article 4 of the General Principles provides: "Civil law activities must respect the principles of voluntariness, fairness, compensation of equal value, and good faith."

30. Article 5. Normally the General Principles uses the term "citizen" where most civil codes would use the term "person." However, although the heading to chapter 2 is "Citizens," this is immediately followed by the word "persons" in parentheses. This can be translated as "natural persons."

31. Art. 36.

32. Arts. 11, 12.

33. Art. 13.

34. Arts. 14, 16-19.

35. Arts. 20-25.

36. Arts. 37,41 .

37. Art. 54. "A civil law juristic act is a lawful act whereby a citizen or juristic person establishes, changes, or terminates civil law rights and civil law duties." This follows the definition of Windscheid (one of the principal draftsmen of the German Code). See H. Lawson, supra note 23, at 164. For a general discussion, see id. at 164-69.

38. Art. 58. 
German Code which is based on the principle of "private autonomy." 39 The purpose of the law is to give effect to the parties' real intention. Hence jurisitic acts can be annulled when there is evidence of, for example, fraud or duress. ${ }^{40}$

The General Principles then considers representation or agency. Its provisions are not much different from those of Anglo-American law ${ }^{41}$ except that this body of law does not cover tort liability.

The next section of the General Principles deals briefly, and somewhat inconclusively, with property. No doubt this is because of political reasons, ${ }^{42}$ though it is hard to see why mention could not have been made of the difference between movable and immovable property.

Continuing the order that Gaius gave to the civil law in the second century, ${ }^{43}$ the General Principles then considers obligation law. There is a general definition of obligation:

An obligation is a special rights-obligation relationship created between the parties in accordance with the provision agreed upon in a contract or according to the provisions of the law. ${ }^{44}$

A contract is said to be:

[A]n agreement between the parties to establish, alter, or terminate a civil law relationship. ${ }^{45}$

There are also rules for joint obligations ${ }^{46}$ and other such matters. ${ }^{47}$ In some ways the most important provision is the governing of such items as price, quality, time, and place of performance. This section begins:

If the provisions in the contract as to quality, time, place, or price are not clear, and if it is not possible to determine them from the content of related provisions, and the parties cannot come to an agreement through consultation, the following rules will be used: . . ."48

It would be difficult to find a clearer statement of adherence to the principle of freedom of contract.

Other aspects of obligation law are contained in a section labelled "Civil Responsibility." 49 For some reason, the drafters of the General Principles have

39. W. Flume, supra note 9, at 1-22.

40. In the General Principles, this is covered in art. 58.

41. Arts. 63-70. See, e.g., art. 63.2: "A representative executes a civil law juristic act in the name of the person being represented within the scope of his representative authority. The person represented bears civil responsibility for the representative acts entered into by the representation."

42. See supra notes 15-16. It is really difficult to describe the actuality of property relations in China and still observe the proprieties required of a decorous Marxist.

43. "The whole of the law observed by us relates either to persons to things or to actions." 1 The Institutes of Gaius 5 (de Zuleuta trans. 1946). Obligation law is included in "things."

44. Art. 84.

45. Art. 85 .

46. Art. 87.

47. Such as guarantees, art. 89; assignments, art. 91 .

48. Art. 88 .

49. Arts. 106-34. 
adopted a French approach for this portion ${ }^{50}$ despite the dominant German influence. The rules in this section deal with breach of obligations and resulting civil responsibility or liability. While this section contains provisions on breach of contract, the most important provisions of the "Civil Responsibility" section relate to torts; liability is created for injuries occasioned both by fault and without fault (particularly in the case of product liability). ${ }^{51}$ The General Principles also includes other miscellaneous provisions, such as rules on domicile, ${ }^{52}$ prescription, ${ }^{53}$ and the like; ${ }^{54}$ but the provisions discussed above are the most important ones for obligation law.

If that were all there was to the Chinese statutory law of obligations, it would be quite clear that this law breaks sharply from the general ideas that have characterized Chinese society since Liberation. There is, however, more to Chinese civil law and obligation law than these general rules. As was pointed out above, ${ }^{55}$ Wang Hanbin, chairman of the committee that supposedly drafted the General Principles, stated that the committee decided not to draft a complete civil code, but instead to supplement the General Principles with a number of special statutes. Of the statutes mentioned, the one that is important for obligation law is the Economic Contract Law. In a formal sense, then, Chinese obligation law consists of the General Principles and the Economic Contract Law. There are still a great many gaps in the law, a fact that Wang Hanbin made quite clear; but he did not indicate how they were to be filled.

There seem to be two obvious ways to fill the gaps of Chinese obligation law. One is by means of treatises; Chinese treatises on obligation law, as well as treatises from Europe, Japan, and Taiwan, are readily available in China and deal with matters not covered in the statutes. ${ }^{56}$ They are a normal source

50. The term is used by French jurists (although it is not used in the Code) to describe that body of law that deals with the duty to repair injuries caused to another. It includes liability for breach of contract, tort, and quasi-contract.

A person is civilly responsible when he is held to repair an injury suffered by another. He will make it good. . . . A bond of obligation arises between the one who is responsible and the victim: The first becomes the obligee and the second the obligor to make reparation. Both without their having intended it. . . .

Civil responsibility is divided into two branches: on the one hand, delictual and quasidelictual; and on the other, contractual responsibility. ... Contractual responsibility is that which results from a breach of an obligation that arises out of contract. . . Delictual or quasi-delictual responsibility does not arise out a breach of contract; it arises out of a delict or quasi-delict.

2 H. L. \& J. Mazeaud, Leçons de Droit Civil 305, 307 (2d ed. 1962) (emphasis in original).

51. Art. 106. Art. 106.3 provides for recovery without fault when the "law" so provides. The two principal situations in which the General Principles "so provides" would seem to be liability for defective manufactured products, art. 122, and liability for ultrahazardous activities, art. 123. See also art. 124, liability for injuries caused by failure to observe state environmental protection rules.

52. Art. 15 .

53. Arts. 135-41.

54. E.g., Conflicts of Laws $\$ \S 142-50$.

55. Supra note 25 .

56. One of the most widely used in university law departments through 1987-88 is MiNFA YUANLI [Principles of Civil Law] (Tong Rou rev. ed. 1985), translated as General Principles of Civil Law (W. Jones trans. 1989). It explains such matters as the difference between conditions subsequent and precedent, id. at 105; between negligent and intentional fault, id. at 180-81; and between movable and immovable property, id. at 91 . 
of law in Roman law systems. Another source for rules is the regulations that seem to be normal in Chinese legislative practice. There are a number of regulations in the field of economic contracts. For instance, in a collection of materials compiled in Shanghai in 1985-about the time the draft of the General Principles was being circulated for discussion-there are seven sets of regulations for different kinds of economic contracts: contracts for the sale of industrial and mineral goods, contracts for the sale of agricultural sideline products, contracts for loans, contracts for property insurance, contracts for hire-processing, contracts for construction, and contracts for survey and design. ${ }^{57}$ There are probably more that were not on the list.

The Economic Contract Law and its regulations do not manifest the light of nineteenth-century German legislation quite so clearly as the General Principles does. That is, they do not give as much scope to the exercise of the will (by means of the juristic act) as the General Principles does. Much more emphasis is given to direction by superior authorities often by means of the plan.

This is clear if one looks at these statutory materials. The Economic Contract Law is comparable to article 3 of the Uniform Commercial Code, whereas the General Principles is more like article 2. Under article 2, the parties are almost completely free to agree to anything they wish. Almost every section, from risk of loss to alternative dispute resolution techniques, can be varied by contrary agreement. In article 3 , on the other hand, a party can elect to execute a negotiable instrument and control the type of the instrument, the amount, and other matters such as interest and security; but most of the rules are mandatory. If an instrument does not read "to order" or "bearer," it is not negotiable. If the endorser is not given proper notice of dishonor, he cannot be held liable, and so on. In the Economic Contract Law, the parties can set a price in a contract for the sale of goods if "government policy permits a negotiated price"; 58 contracts for scientific and technological cooperation may be concluded by negotiation between the parties "in the absence of ... a plan."59 On the other hand, leases seem to be pretty much up to the parties to arrange, ${ }^{60}$ although it seems improbable that there is any use of land that is not subject to control. All contracts must be in writing, ${ }^{61}$ and all must contain certain terms. ${ }^{62}$ The Economic Contract Law governs only economic contracts between juristic persons. ${ }^{63}$

The Economic Contract Law is organized in a way that is fairly similar to that of the special part of the law of obligations in a German system. That is, first there is a general part containing rules to be used throughout the act. This is followed by rules for particular contracts such as sales, construction,

57. Supra note 31 .

58. Economic Contract Law $\S 7.3$.

59. Id. $\S 26$.

60. Id. 823 .

61. Id. \& 3 .

62. E.g., id. \& 12.

63. Id. $\S 2$. 
loan, lease, and so on. ${ }^{64}$ The content of the Economic Contract Law is not the same, however. In the German Code, the special part follows the same principle of freedom of contract as the general part. Most of the provisions are simply applicable to fill the gaps left by the failure of the parties to agree otherwise. They are "dispositive" (optional) rules as opposed to "zwingende" (compulsory) rules, of which there are few (good faith being one). ${ }^{65}$ As indicated, the Economic Contract Law contains a number of compulsory provisions.

The result is that the Chinese statutory law in the field of obligations is composed of two somewhat inconsistent elements. One, the General Principles is based on the Western idea of freedom of contract. It also contains all of the provisions on tort law. To the extent that treatises can be regarded as a source of law, they reinforce this approach. The other principal statute, the Economic Contract Law, is based on the idea that parties only enter into obligation relations that are permitted by the state and frequently only as they are directed by government officials. These contracts are subject to a number of restrictions as to content and form. The regulations are even more restricting, as will be shown. So far as it appears, there is nothing so systematic as the Economic Contract Law in the field of torts, but the same split seems to exist.

\section{How Would This formal System of Law Be Applied to Contracts?}

Perhaps the formal law of obligations can be best discussed by considering how it would be applied to a particular contract-the processing contract. ${ }^{66}$ The processing contract is one type of the Roman law contract of "hire" (locatio conductio). ${ }^{67}$ Traditionally, it involved a commissioning party who contracted with a contractor to construct or repair a building, to make or clean clothes, or to make a gold ring, for example. The German Codefollowed by that of Nationalist China-distinguishes between the contract for services and the work contract. ${ }^{68}$ In the former, the object of the contract is for one party to obtain the services of the other contracting party such as an

64. See 1 E. Cohn \& W. Zdzieblo, Manual of German Law 62-63 (2d ed. 1968).

65. 2/1 K. Larenz, Schuldrecht 4 (13th ed. 1986).

66. I have selected for consideration a processing contract, and for reference I have quoted the texts of the relevant provisions of the Economic Contract Law and have also made use of the regulations on Contracts of Hire-Processing. I have translated the Chinese term as "HireProcessing" because it is my feeling that the word the Chinese use to refer to that type of contract is a translation of locatio conductio (by way of the German probably) and "hire" is the normal English translation of the Latin. This is the usage of the official translator of the Civil Code of Taiwan. See ch. 2 , tit. 7.8 .

67. See B. Nichol.AS, supra note 15 , at $182-85$.

68. The contract for services-Dienstvertrag-is covered in BGB $\$ \S 611-630$ (W. Ger.) and in $\S \S 482-489$ of the Civil Code of the Republic of China. The Werkvertrag is covered in BGB $\$ \S 631$ 651 (W. Ger.) and $\$ \$ 490-514$ of the Chinese Civil Code. The Roman law contract is considerably broader. It includes, for example, leases; see B. Nicholas, supra note 15, at 182-85. 
architect. In the latter, it is not the services as such that are sought, but the accomplishment of some specific task or work such as the building of a house. The Economic Contract Law, like the Civil Code of Soviet Russia, omits any mention of the service contract-no doubt for ideological reasons ${ }^{69}$-and divides the work contract into construction contracts ${ }^{70}$ and processing contracts. ${ }^{71}$ There are provisions and regulations for both types. ${ }^{72}$

How does this group of materials work together? Suppose the First Department Store in $X$ City wishes to market a line of spring dresses manufactured according to a set of Vogue patterns which it has obtained from the United States. It arranges with the Number 3 Clothing Factory of $X$ to do the work. It gives the factory the patterns, colors, quantities, and sizes. (No mention is made of types of fabric although each pattern indicates certain recommended types.)

The biggest problem with this type of contract is probably performance, particularly quality control and inspection. It is extremely difficult to get manufacturers to meet high quality standards in China. There almost always have to be many rejections, reworkings, adjustments of the price to reflect low quality, and the like. Delays are commonplace. These problems exist even when the factory is turning out a simple standard product (one has only to observe the great suspicion with which Chinese in a department store examine such manufactured products as pots and pans for defects). When the product is new and complicated, the problems multiply.

Other problems will almost certainly arise with this sort of contract. The commissioning party - the department store-will want an assured supply at a definite time, particularly since these are seasonal garments. The patterns will probably not work exactly as printed; for one thing, the sizes will have to be adjusted to fit Chinese women. The fact that the specifications are in English could cause a lot of trouble. What should be done about fabric specifications? What about substitutions for particular colors, patterns, and types if some of those specified are not available? What about delays in supplies? What if the type of seam specified is different from what is usual in China (or this factory), or the workers are simply unable to make the seam with their machines? In

69. To have a provision in the civil code that regulates the device whereby an employer obtains the labor of another for a fee might seem to sanction the exploitation of man by man.

70. Sec. 18.

71. Sec. 15 .

72. I do not know of any translations of these regulations. As of Jan, 1, 1986, seven were contained in a collection of statutes and regulations made in Shanghai. FaLü XINXI (INFORMation on Laws and Regulations) (Shanghai Municipal Economic Law and Regulation Research Center and Shanghai Municipal Economic Law Research Group eds. 1986). These were sales, id. at 8-9, 28; sales of agricultural sideline products, $i d$. at 8-5, 46; loans, id. at 8-9, 56; insurance, id. at 10, 8; hireprocessing, id. at 10, 14; construction contracts, id. at 10,21; and inspection and survey contracts, id. at 10,27. There are also unpublished internal regulations. See Chang, The Great Battle of the Forms, China Bus. Rev. 10, July-Aug. 1987. There are also other regulations on related matters such as product quality. See, e.g., State Council, Law of the People's Republic of China on the Supervision of Medicine 780 (Bulletin No. 23, Oct. 10, 1984). Section 23 provides: "Medicine must meet the standards for medicine of the state, the province, the autonomous region, and the directly administered city." 
addition, the seam specification may not work with the Chinese fabric. Some of these problems could be resolved by having a trial run of the production line, but sometimes, though a trial works well enough, hitches develop when actual production begins. Some defects may not be discovered until the dresses are in the hands of customers. Some foreign fabric or other material, such as buttons, may be required. This would require a foreign exchange allocation (to say nothing of actually arranging to import the materials). It would be possible to provide for most of these problems in a contract if one foresaw the possible contingencies, and if one operated under the principle of freedom of contract. But suppose the contract did not cover the matter. For example, suppose the commissioning party decided, on receipt of the goods, that a "navy blue linen-polyester" that was used by the manufacturer and that purported to meet the specifications was not the color it had in mind and did not work out well with the pattern. Suppose also that the party did not like the fabric, or wished to reject or have some changes or adjustments made in the dresses. What happens when the contract is silent as to color, type of material, inspection, and adjustment of disputes?

The General Principles permits the parties to provide any system of inspection, rejection, cancellation, arbitration, and so on that they wish. If they do not provide for some of these problems in the contract, however, the General Principles offers no solutions. Of course it would be possible for an adjudicatory authority to work out solutions to these problems on the basis of general principles, perhaps by using something like the objective or reasonable man standard. It is not at all clear, however, that the Economic Contract Law permits this approach. If it were in fact like the special parts of the German Code, its primary function would be that of gap-filling, since, in the final sense, the parties are free to make their own agreements. It is not clear that this is the case.

The first requirement of this law is that the contract must be in written form. ${ }^{73}$ This seems to be a condition for validity (like our statutes of wills), not a proof requirement (like our statutes of frauds). It is not clear what this means for interpretation. For instance, what materials from outside the four corners of the document can be considered? This could cause problems for any court attempting to work out an objective standard. More important is section 4, which requires that the contract "conform to the requirements of state policies and plans." Otherwise, there does not seem to be anything in the general part of this law that helps or hinders in solving the problems of our contract.

Chapter VI of the law, "Managing [Administering] Economic Contracts," is a subject that does not exist in German law since it is up to the parties to

73. Sec. 3 provides: "Economic contracts, with the exception of those that are settled immediately, shall be in written form. Documents, telegrams, and charts which are related to contract amendments and are agreed upon by the concerned parties through consultations are also component parts of a contract." I take this to mean that the word translated "contract" is intended by the draftsmen to refer to a formal document that includes the essential elements of the contract, though it can be interpreted by reference to supplementary materials. 
administer their own contracts. Hence, even the chapter heading is significant. There are two interesting provisions:

Section 51. All responsible business departments and departments of industrial and commercial administration at all levels should supervise and examine economic contracts concerning them. They should also establish systems of control. The responsible business departments at various levels should also regard the implementation of these economic contracts by enterprises as one of their economic indexes for checking.

Section 52. The people's banks, specialized banks, and credit cooperatives should supervise the implementation of economic contracts through the management of credits and account settlement.

The people's banks, specialized banks, and credit cooperatives should settle accounts in accordance with the provisions prescribed in the system concerning the settlement of accounts. They should also handle such cases as the payments made or rejected by one party to another and the detaining of the amount of money whose payment is delayed.

If the parties of an economic contract fail to implement automatically the mediation agreements, arbitration decisions, or verdicts of the people's courts within the prescribed time limit, the people's banks, specialized banks, or credit cooperatives should, after receiving notification from the people's courts which help enforce the implementation, detain or transfer the amount of money from the accounts of the parties for necessary payment.

It is not clear whether these sections refer to both formation and performance of contracts, or just to performance. It seems likely that they refer to both. Consequently, it is quite possible that the department store and the factory in our hypothetical would never have entered into this relationship without considerable interference from their superiors. It might well be that both the proposal and the final contract would have to be reviewed before execution. It seems to be contemplated that local authorities will issue regulations in addition to those issued by the state.

After its general provisions, the Economic Contract Law breaks contracts down into types, following the organization of German-style obligations provisions. Indeed, many of the types of contracts are found in European codes, and go back to Roman law. Some, however, are peculiar to China. They are: Sales, ${ }^{74}$ Hire-Construction, ${ }^{75}$ Hire-Processing, ${ }^{76}$ Transportation of Goods, ${ }^{77}$ Contracts for the Use and Supply of Electricity, ${ }^{78}$ Storage, ${ }^{79}$ Lease, ${ }^{80}$ Loan, ${ }^{81}$ Property Insurance, ${ }^{82}$ and Scientific and Technological Cooperation. ${ }^{83}$ Remedies are arranged-rather oddly, as drafting techniques go-according to type of contract, in a separate chapter. That is, there is a

74. Sec. 17.

75. Sec. 18. The Chinese do not use the term translated "hire" in sec. 19 , but it seems to me to be a contract that is clearly derived from the same root.

76. Sec. 19 .

77. Sec. 20

78. Sec. 21

79. Sec. 22.

80. Sec. 23.

81. Sec. 25.

82. Sec. 25.

83. Sec. 26. 
separate section for the particular remedies for breach of a sales contract, ${ }^{84}$ another for breach of a lease contract, ${ }^{85}$ and so on.

The contract in the hypothetical is clearly a contract of "hireprocessing." It is provided for in section 19:

Processing contracts shall be made in accordance with the names of the articles, the items and the quality requirements set forth by the ordering party, and the contractor's capabilities for processing, filling the order, and making repairs. Unless otherwise specified in the contract, the contractor must complete the main part of the processing, the order and the repairs of its own equipment, technology and labor, and shall not assign the accepted work to a third party without the consent of the ordering party. The ordering party should receive the articles or the work products completed by the contractor and pay remuneration.

The contractor shall promptly examine the raw materials and other materials provided by the ordering party. If such materials are found not to conform to specifications of the contract, the contractor shall immediately notify the ordering party to replace or supplement such materials. The contractor shall not arbitrarily replace the raw materials and other materials provided by the ordering party or covertly change any parts of the article being repaired. Violating contractors shall be liable to provide compensation.

In repairing houses or in mass processing of non-standardized articles, the contractor shall accept necessary inspection and supervision by the ordering party; but the ordering party shall not hamper the normal work of the contract. If confidentiality is requested by the ordering party regarding duplication, design, translation, and tests and examinations of product properties and other work contracted, the contractor shall strictly comply with such request.

If the ordering party fails to make delivery of the ordered articles more than six months after the prescribed time, the contractor shall have the right to sell the ordered articles and deposit the sales proceeds in the bank in the name of the ordering party after deducting the remuneration and storage charges.

The statute seems to include under this heading both contracts for the processing of goods furnished by the commissioning party, and contracts to manufacture goods to order from materials to be furnished by the contractor (the Werklieferungsvertrag). There is no specific provision in the law on contracts of hire that refers to the state plan as there is for both sales and construction contracts. However, as indicated above, other provisions seem to contemplate such a reference. There is also the implication in section 27 , governing amendments of all contracts, providing that one of the situations in which amendment is permitted is: ". . . 2) If the state plan on the basis of which the economic contract was concluded is amended or cancelled."

This may imply that all contracts are executed on the basis of a plan. It may be that the drafters of the statute did not realize the possible economic significance of the hire-processing contract as defined in this section and hence did not make a specific reference to a plan. That is, they may have considered a contract for the repair of a building as the typical example of this type of contract. But it seems clear that all contracts for the sale of such items as turbogenerators would be covered by this section because goods of that kind are all, in effect, made to order for particular projects. Since any transaction that involves manufacture to specifications would be included

84. Sec. 38 .

85. Sec. 44. 
under this heading, ${ }^{86}$ a very large percentage of the contracts we label as "sales" would be labeled as "hire-processing" in Chinese law.

In any event, these provisions of the Economic Contract Law do give some guidance on the regulation of this relationship. ${ }^{87}$ They provide for inspection by the commissioning party and replacement by the contractor in the event of a defect. Implicitly this proceeding is governed by the standards set in the contract. The processing should be done in accordance with the quality requirements of the commissioning party, but there are no precise provisions or standards set out in the statutes. It is also not clear under the statute whether, in a contract like this, it would be permitted to have an inspector from the commissioning party stationed in the factory observing, and, to a degree, supervising the manufacture, although that procedure is permitted in the case of "process[ing] a batch of non-standard articles." Finally, it is not clear whether the provisions in the statute are optional or compulsory. ${ }^{88}$ In other words, the statute itself does not deal explicitly with many problems, nor does it make it clear that these are matters for the parties to decide, expressly or implicitly, nor is there any reference to custom and usage. ${ }^{89}$

Many-although not all-of these problems are, however, cleared up by the regulations. In the first place, there are a number of compulsory provisions. For example, section 5 provides:

A contract of hire-processing must have the following provisions:

1. The name of the item to be processed or the work [for example, advertising] to be done.

2. The quantity, quality, packing, and method of processing.

3. The [method of] supply of raw materials and specifications of quantity and quality.

4. Price or fee.

86. This is made clear in the regulations.

87. All provisions are in sections $19 \& 40$. Sec. 40 provides:

Liabilities for Breach of Processing Contracts

(1) Liabilities of the party undertaking the processing job:

(a) Such party shall be responsible for providing compensation for any damage or loss caused by improper storage of the materials or goods provided by the party ordering the processing.

(b) If the processing job given by the ordering party is not done in accordance with the quality and quantity stipulated in the contract, the processing party shall make repairs and make up the quantity free of charge or reduce the charge. If the work product has serious defects, the processing party shall bear the responsibility to provide compensation.

(2) Liabilities of the party ordering the processing:

(a) Such party shall be responsible for providing compensation for losses caused by work delays resulting from its failure to provide raw and other materials according to the specified time, quality, and quantity.

(b) Such party shall pay the processing party an overdue storage fee if it picks up the processed or repaired goods after the prescribed period.

(c) Such party shall pay a breach of contract penalty fee for late payment if it makes the payment after the period prescribed in the contract.

88. To be sure, there is a good deal of imperative language. For example: "Without the consent of the ordering party the contractor may not assign accepted tasks to a third party. The ordering party shall accept the articles and the results of the work completed. . .."

89. Compare this with the Foreign Economic Contract Law, sec. 5: "Where the laws of the People's Republic of China have not dealt with a matter, international custom may be applied." 
5. Time, place, and manner of performance.

6. The standard and method of performance.

7. The method of settling accounts, the bank in which the account will be kept, and the account number.

8. Penalty for breach of contract. [Literally, liability for breach of contract-but what is meant is a penalty even if there are no damages.]

9. Other provisions agreed on by the parties.

Related written agreements on the technology involved, technological data, papers

[for example, blueprints], and so on are also component parts of the agreement.

It is further provided that the parties "may not sign a contract without a quality requirement and a technological standard." 90 Generally, the price is set by the state. ${ }^{91}$ Whether the commissioning party may pay a deposit or pay in advance is governed by state rules (apparently outside the regulations).$^{92}$ It seems pretty clear that the system of higher office involvement hinted at in section 51 of the Economic Contract Law, discussed above, is the basic operational procedure contemplated by the regulations. In other words, normally the higher offices will decide whether the operating units should engage in a certain processing activity such as making dresses. Probably, many of the details will also have to be decided on elsewhere. On the other hand, this procedure is not the only one used. It seems to be contemplated that the operating units will occasionally make their own decisions. ${ }^{93}$

The drafters of the regulations seem acutely aware of the problems of getting things made to standard in China. They insist on a number of provisions that must be included in the contracts. They are extremely emphatic about quality and technological standards. As indicated above, "the parties may not sign a contract" that does not include provisions on those two points. ${ }^{94}$ The commissioning party is given the right to inspect and to insist that improper work that he observes be redone. ${ }^{95}$ For example, there is a provision that could be interpreted to deal with the "navy blue linenpolyester" problem mentioned earlier. Section 14 provides:

If, while the contractor is carrying on the work in accordance with the requirements of the one commissioning it, it is discovered that the plans or technological requirements are not reasonable, it must immediately notify the commissioning party. The commissioning party must reply within the time provided [in the contract] and make suggestions as to changes. If the commissioned party has not received a reply within the designated time, it has the right to halt the work. It will notify the

90. Sec. 6 .

91. Sec. 8 .

92. Secs. 9-10.

93. For example, the amount of earnest money will be set by the parties but the question of whether there should be earnest money is settled by "related state rules," sec. 9; by implication, the commissioning party can require secrecy, sec. 15; and time for performance is apparently left up to the parties, sec. 18. It is not clear whether the parties can decide to enter into the contract on their own-whether the basic decision to have two parties enter into some sort of economic relation is made by the parties themselves or by some superior authority. If the former situation is possible, then it seems clear that all of the substantive elements of the contract-quantity, description, time of delivery, etc., except price-are subject to decision by the parties. Price can only be set by the parties if there are no state prices. Sec. 8 . If some superior agency decrees the formation of the contract, then presumably it decrees the content of the contract as well.

94. Sec. 6.

95. Sec. 11. 
commissioning party. If, as a result, there is injury, it must be compensated for by the commissioning party.

This provision seems to give the contractor both the right and the duty to notify the other party, and to stop work, when difficulties arise. The two parties are then supposed to adjust the matter. Thus, in our case, if the contractor had trouble with the material specification, he should have given notice.

The commissioning party also has a duty to supply materials that are of contract quality. ${ }^{96}$ There is a provision for what happens when the plans for the work that are furnished by the commissioning party do not work. ${ }^{97}$ There is also a provision for arbitrating disputes over quality separate from the general scheme for resolving breach of contract disputes. ${ }^{98}$

Despite the fact that the regulations are often mandatory, they do not make it clear what happens if they are not followed. Is there a contract? That may not be a meaningful question. It may be that the regulations are not really designed to dictate the terms of a contract so much as to guide conduct - to instruct the parties as to what they ought to do in a certain type of relationship. They seem not to be designed to fill in the gaps where the parties have left things open, nor to regulate or limit the discretion of the parties. Rather, they are more like instructions as to how certain business is to be carried on. One example of this might be a requirement that automobiles be washed once a week and lubricated every 3000 miles.

This may be a fairly accurate statement of the way business is, in fact, carried on in China at present. Enterprises are certainly not, in general, free to do as they wish. On the other hand, there is a certain amount of discretion allowed, or at least exercised, as to the content of a contract (or contract-like relationship), its performance, and, occasionally, even as to its formation. The parties are quite inexperienced, however, and need guidance in carrying out the task. This seems to be implied in the definition of an economic contract in the Economic Contract Law, section 2. It states that the economic contract is an agreement "between legal persons for the purpose of realizing certain economic goals and clarifying each other's rights and obligations."

\section{IV}

\section{What Is Really Going on in the Formation and Performance of Contracts?}

It is impossible to know exactly what is, in fact, going on in China in connection with the formation and performance of economic contracts. No Westerner is in a position to make a study of actual practice (say, of all the economic contracts in 1986), and the Chinese do not seem to be very interested in law-in-action studies. It may be that scarcely anyone ever looks

96. Sec. 12.

97. Sec. 14.

98. Sec. 17. 
at the Economic Contract Law or any other law outside of the classroom. Business entities enter into relations with each other without bothering lawyers, but the model of contract formation and performance that appears in the regulations is consistent with some evidence found on actual behavior at the time the Economic Contract Law was enacted. That is, despite the fact that there was no formal law that recognized "juristic persons," and though all significant economic activity was still planned at that time, there are case reports available for the period 1979-80 that indicate a number of instances in which operating units of various sorts-factories, communes, marketing units-engaged in independent contract arrangements among themselves. For example, a hardware store agreed to sell red-based lacquer for 6327.50 yuan (and got a bad check in payment);99 an electrical installation team agreed to make an electrical installation on the property of a production brigade; ${ }^{100} \mathbf{a}$ commune sold $6,125,000$ onion sets to a production team; ${ }^{101}$ a factory bought potatoes from a production team and paid by check which the seller raised in order to pay itself for some processing contract, ${ }^{102}$ and so forth. From the reports in the cases, these contracts seem to have been very badly drafted. The parties had not provided for all the eventualities in the way one hopes a good American lawyer would; and the result was a situation that was very tangled and hard to work out. It is easy to see why planning authorities might think that getting entities to follow routines would aid economic development. If they had had "contracts" that spelled out the steps they should take in performing contracts, they might have been able to avoid a lot of the difficulties and delays that occurred.

If these cases are typical, then it seems that prior to the current (or recent, if it is now changing back) changes, there was a fair degree of de facto autonomy in handling economic activities although there was nominal subservience to direction. Now, perhaps one would characterize the situation as nominal autonomy with de facto subservience to superior direction. The Economic Contract Law and its regulations, if used, could help work out problems that might develop by giving guidance both to the contracting parties and their supervisors. The General Principles, however, is too removed from this reality to be of much use. ${ }^{103}$ It is not clear that anyone, in fact, refers to any of these laws.

99. The cases discussed here are all contained in a collection translated in Civil Law in China, 28 Chinese Law and Government 24 (Nos. 3-4, 1985-86). This case is no. 8, id. at 33.

100. Case No. 11, id. at 37.

101. Case No. 18, id. at 52.

102. Case No. 26 , id. at 74 .

103. It is not only that the General Principles does not purport to give anything except very general rules, but that its structure is almost incomprehensible to anyone who does not have a university legal education. The German Code was drafted by professors and is very academic. H. LAwson, supra note 23, at 53,54. There is considerable dissatisfaction with the "General Part" even among Germans. Id. at 167-68. 
TORTS

In the field of torts, the General Principles does not share the field with any other comprehensive statute like the Economic Contract Law. What there is to Chinese statutory torts law is contained in the General Principles. It is not, by American standards, very extensive; but Continental civil codes normally give short shrift to torts as compared to contracts.

Although the violations of rights that the United States labels as "torts" are categorized along with contracts and restitution under the label "Obligation Rights" (articles 84-93), there are no provisions in that chapter that deal specifically with torts. As indicated above, they are dealt with explicitly under "Civil Responsibility" (articles 106-134), along with remedies for breach of contracts. Of course, the problem of capacity is dealt with under the chapter on "Persons" (articles 9-13).

The General Principles declares that a citizen or juristic person is liable for injuries caused to the person or property of another as the result of fault. ${ }^{104}$ There is also civil responsibility (liability) for injury caused without fault if the law so provides. ${ }^{105}$ If one caused the injury because of unavoidable circumstances, one is not liable unless the law provides otherwise. ${ }^{106}$ The General Principles provides for non-fault liability for manufacturers and sellers of defective products that cause injury, ${ }^{107}$ and also imposes non-fault liability for injuries caused by ultrahazardous activities such as using explosives or radiation. ${ }^{108}$ No distinction is made between negligent and non-negligent fault. The remedies provided include both damages and various types of specific relief, such as repair and apology. ${ }^{109}$ In other words, there is a system of tort liability that is similar-although not identical-to that in the United States. The same is true for restitution. Both unjust enrichment ${ }^{110}$ and management of the affairs of another (negotiorum gestio) are provided for. ${ }^{111}$

The scope of personal injury damages in Chinese practice is anyone's guess. There certainly is occasional recovery of damages by one private individual from another private individual for tortious injuries. ${ }^{112}$ There is at least some evidence of suits against enterprises for negligently caused injuries, ${ }^{113}$ but it seems improbable that personal injury is very important at the present time. It seems unlikely that an individual Chinese-natural or

\footnotetext{
104. Art. 106.2

105. Art. 106.3.

106. Art. 107.

107. Art. 122.

108. Art. 123.

109. Art. 134

110. Art. 92.

111. Art. 93 .
}

112. At any rate, there was such recovery prior to the General Principles. See, e.g., Case No. 35 in Civil Law in China, supra note 99, at 90 (parents of children who had caused injury from fireworks were held liable).

113. See Case No. 13, id. at 46 , where an action for medical malpractice against a hospital is reported. Although the plaintiff lost on the facts, the principle of liability was recognized. 
juristic person-would, on his own, bring a successful action before a Chinese court against a significant defendant-a factory or industrial enterprise for example-for injury resulting from a defective product or an accident suffered on the job unless some superior organization approves both the suit and the result. In other words, the suit could not be brought unless perceived as having some general utility, most probably its educational value. The suit would point up a problem-defective goods, unsafe working conditions, or whatever-and allocate the blame. Of course, enterprise liability for personal injury could be simply one of many battles in some bureaucratic war.

One would expect that the normal control device for defective products and injury-producing behavior, such as careless driving, will be administrative and criminal procedures. ${ }^{114}$ There is some evidence that this is the case. For example, there are statutes that deal with improving ${ }^{115}$ and regulating the quality of goods in general, and certain special types of goods such as medicine in particular. ${ }^{116}$ These contemplate enforcement by means of administrative and criminal measures. In addition, the press is full of reports of efforts to control behavior by criminal or administrative measures that would be the subject of private tort litigation in this country. For example, in July 1987,117 there was a report that the procuracy was intensifying its "efforts to curb dereliction of duty which [was] causing heavy casualties and economic losses." It is not clear with which sorts of behavior the procuracy is concerned. The only detailed example given is of school officials who were imprisoned because they contracted with an unlicensed builder to construct an additional lavatory that collapsed, causing twenty-eight girls to drown. There were no safety checks, and "the principal and his assistant failed to listen to warnings that it might fall down." The aim seems quite broad and not confined just to industrial incidents. One official said, "Our focus is on major cases mostly found in the fields of credit and loans, purchases and sales, production and transport, construction, storage, and medicine." There are frequent efforts to deal with defective products, particularly those that affect health. ${ }^{118}$ Of course, even in the United States where the personal injury action has become a major industry, administrative and criminal control devices are used. It is my impression, however, that the emphasis in the two countries seems very different and likely to remain so.

114. Criminal penalties are contemplated in the General Principles, art. 134. Civil, administrative, and penal liability are contemplated in the Economic Contract Law, sec. 32.

115. State Council, Methods for Supervising the Testing of Product Qualty 239 (Bulletin No. 164, Apr. 10, 1985) (promulgated on Mar. 7, 1985).

116. Supra note 72 .

117. China Daily, July 27, 1987, at 1 .

118. See, e.g., Poor Drugs Lead to Fining of Two, China Daily, July 15, 1987, at 3 (managers of a drug factory fired). See also Food Quality Rises But Still Needs Improvement, id. at 1 (where the work of food inspectors is described). 


\section{Conclusion}

While the enactment of the General Principles would seem to have effected a potentially revolutionary change in the Chinese legal system, there are no signs that such a change is, in fact, taking place. In the formal sense, the very clear thrust of the General Principles in the direction of private autonomy is belied by the continuation of the philosophy of directed activity exhibited by the Economic Contract Law and the regulations issued under it. While it is not clear whether or not these statutes actually determine action in China any more than the General Principles will, they seem to be closer to the Chinese reality than the more abstract General Principles.

It must be remembered that during the period since Liberation, China has developed a system (or perhaps systems) of civil law that covers activities that the United States deals with by means of obligation law (torts and contracts). However, no one knows exactly how this system works. Foreigners have never been able to study the Chinese system closely, since it is an aspect of the internal administration of the country. The Chinese do not seem to have been interested in the matter, at least publicly. The activities of planning authorities have obviously been very important in allocating goods and services and regulating production, all matters of concern to a civil law system in the West. China, however, has not been a monolithic society, the model bureaucratic nation in which all decisions are made at the center and sent down the line for automatic implementation. There has been a good deal of local autonomy. Goods have been distributed according to agreements or arrangements that no lawyer or planner ever saw. While courts, for the most part devoid of legally trained judges and lawyers, occasionally settle disputes, they do so on the basis of reasons that are usually unclear, and that seem to have little to do with anything we would recognize as a formal legal system. In any event, disputes are normally settled by negotiation and mediation, and again, probably without any reference to the sources of law that have been discussed here. This legal culture will not disappear completely, regardless of what decisions are made in Beijing. It is likely that enterprises will continue to make arrangements with other enterprises without bothering to consult the law. Sometimes they will be fairly closely controlled by superior authorities and a plan, sometimes not.

On the other hand, the enactment of the General Principles indicates that the government and the Party have decided to have China join the Western legal world. The civil law which has been taught in a somewhat disembodied way in the law schools (since there was no Chinese code to refer to) will now be taught by reference to a promulgated Chinese statute. The substance will not be markedly different, but the atmosphere may change. If the law graduatesboth graduates of university level departments and graduates of short courses-assume important roles in China, the Germanic ideal contained in the General Principles may become influential. But the resulting system will inevitably be an amalgam with elements of both centralization and autonomy. 
If some autonomy develops in fact, if the individual responsibility system really takes hold in the industrial and commercial sectors, this social fact could in turn be very influential on the way the law actually functions. Autonomy in legal theory and social fact could reinforce each other.

There is also the problem of the other legislation that exists in China. There is an immense body of published legislation, enacted since Liberation, that has been collected but not codified. Most of it is still in force. It has not been assimilated into the civil law treatises, but it deals with the same issuesdistribution of goods and services, for example. The statutes that decreed what crops will be raised and how their prices will be set in effect "create, annul, and alter rights" - the standard definition of a juristic act. The decisions reflected in these statutes are made outside the area of application of the General Principles and the Economic Contract Law. Of course, this situation is true not only of China. The federal budget is a source of obligation law in the United States, although it is rarely analyzed in that way. But in Western nations, the civil law came first. In China, most of the law that was in effect when the General Principles was enacted was public, not private. ${ }^{119}$ It should be added that there is also apparently a great deal of legislation, including local regulations, that is not published, at least for foreigners. ${ }^{120}$ No statement on the operation of the new Western-style legislation will have much meaning until its relation to this body of material is understood.

The easiest way for a Western jurist to treat Chinese law is to regard it as being the same as a European system, and thus to analyze the normal legal materials-statutes, regulations, treatises, and cases, if any-in the way they are analyzed in Europe, where it is reasonable to assume that parties adjust their behavior in the light of the law, and where intervention by courts that interpret and enforce the law is a realistic possibility. None of this is true for China. On the other hand, it would probably be a mistake simply to dismiss Western-style law as having no real significance in China. Even if that is true now (despite all the drum-beating in the press), it probably will not continue to be true unless there is a sharp reversal of the present official position on law. Consequently, it seems wise to continue to observe the official developments while trying to get as much information as possible on what is really going on. We are unlikely to get enough information to be satisfied that we really understand the situation. Still, the Chinese observers in China do not seem to be much better off, and we are free to say what we think. Perhaps our efforts will be worthwhile.

119. I have considered some of this legislation in An Approach to Chinese Law, 4 Rev. Socialist L. 3 (1978).

120. Even the drafts of the proposed civil code were classified for "internal use." 


\section{AFTERWORD}

This article was written in the summer of 1987. At the time I was not sanguine about the future of Chinese law, but I did not anticipate anything remotely like the events of the spring and summer of 1989. It is quite obvious that the present Chinese Government pays no attention to rules of law in the field of constitutional and criminal law. The point was forcefully made by Professor Cohen in the Far Eastern Economic Review:

The events surrounding the Tiananmen tragedy have gravely damaged this nascent legal system, demonstrating the current leaders' low regard for law even while they profess to observe it. When their own political power was at stake, they respected the rules of neither the party nor the state. Indeed, it appears that, in recent years, the party has secretly operated on an illegitimate basis. . . .

The reign of terror has already demonstrated how little the guarantees embodied in the 1979 codes of criminal law and procedure and China's adherence to the UN convention against torture can mean for those accused of "counter-revolution." Deng, Peng Zhen and other leaders, who in the 1950s had mastered the techniques of cloaking political repression in forms of law lacking in substance, have reverted to familiar techniques. No protection against beating, torture and public humiliation while in police custody. Insufficient time to prepare a defence or appeal against "facts" presented by a regime that claims no students died at Tiananmen. Trial in a coercive environment presided over by courts that once again trumpet their role as instruments of the state.

By blatantly directing facts and manipulating law and legal institutions, they have devalued the currency of not only their country's domestic legislation but also its international agreements and made mockery of the "basic law" being drafted to assure Hong Kong's autonomy after 1997. And, in the eyes of foreign individuals, companies and governments, all these actions make China a riskier place, a less trustworthy partner. 121

If any progress has in fact been made towards the establishment of a criminal law system that would function in a way that bore some relation to the Code of Criminal Procedure and the Penal Code, that movement has now come to an end. It is not only that the government acts in total disregard of the law. The young lawyers and law students on whom the success of the new system must inevitably depend are almost certainly completely disillusioned with it. It seems probable that they go through the motions because there is nothing else to do, but the sense that something that was important for China was being accomplished must be gone.

Civil law is in a somewhat different case. The government purports to want to continue the economic development of the last ten years, and is apparently still interested in foreign investment. There would not seem to be any political reason why a civil law system could not continue to develop. However, there are at least two factors that make it unlikely that it will. In the first place, the malaise that affects the legal community will inevitably affect civil law. The law students and young lawyers who are China's best and brightest and who have become cynical about criminal and constitutional law

121. Cohen, Law and Leadership in China, FAR EASTERn Econ. Rev. 23 (1989). 
are not likely to become enthusiastic about developing a law of negotiable instruments. Law is simply the boring and meaningless niche they have fallen into and there is no place else to go unless they are lucky enough to get an exit permit and visa. In addition, the economic structure that was the reason for pushing civil law and the new code is under heavy attack. That is, the movement to create a relatively free economy has apparently been reversed, and centralized planning has been restored. ${ }^{122}$ Civil law has little role to play in such an economy. There is no place for contracts, for private autonomy.

Yet things in China are not always what they seem to be. Even during the Cultural Revolution the reports of civil law cases show that there was some private economic activity that did not seem much affected by central directives ${ }^{123}$ and there was widespread disregard for authority at the local level. ${ }^{124}$ Just as the promulgation of a civil code and the opening of a few law schools did not mean that China had really entered a new legal era, the announcement of a new economic policy does not mean that all of the independent managers and local officials will get back into their Mao jackets and start relying on moral suasion instead of material incentives to industrialize China. It is even possible that the continuing introduction of young people who have been trained in civil law into urban society (few law graduates go to rural areas) will help to create a consciousness that thinks of society as composed of discrete rights-bearers and decisionmakers rather than as a centrally directed whole. This is the societal model both of Western civil law and of classical or market economics. Jurists are an infinitesimal part of the total Chinese population, but they constitute a significant percentage of the younger urban educated elite.

122. See Delfs, Power to the Party, Far Eastern Econ. Rev. 23 (1989).

123. See, e.g., Civil Law in China, supra note 99. In Case No. 22, id. at 65, in 1971 a Soviet citizen rented out three rooms of her apartment to a Chinese; in Case No. 11, id. at 39, a brigade made a contract in 1969 with an electrical installation team for electrical design and installation; in Case No. $47, i d$. at 113 , in 1971 a commune member erected a three-room house on his private plot without permission and then entered into a contract through a broker to sell the original one-and-a-halfroom house-both actions that were "contrary to policy."

124. See, for example, the case labelled "Having Done Detailed Ideological Work, Two Civil Judgments Are Carried Out," in Jones, Collection of Civil Law Cases from the People's Republic of China, 10 Rev. Socialist L. 169, 191 (W. Jones trans. 1984). In that case three citizens occupied a public building of a production brigade and were ordered by the court to return them. They refused to obey, and got together 40 friends to tear down part of the building. They ignored education and made fun of the law. Some local cadres were afraid of them. They were eventually brought under control but only after a major application of force. In some ways, Case No. 22 in Civil Law in China, supra note 99 , at 65 , is similar. The Chinese who was ordered to vacate the apartment of the Soviet citizen went around "making false accusations regarding the judicial officers" and parading his blind daughter (to get sympathy from the people presumably). He apparently had some success in delaying execution. In all of the cases reported in these official collections, the courts eventually enforce their judgments-otherwise they would not be reported-but it is clear from the kinds of disputes that arise that the population is not docile or easily controlled. The situation has not changed. In 1988 three judges from the people's court who attempted to enforce a judgment against an enterprise were manhandled, beaten, and struck with electric prods before a street crowd of over 1000. The judges were apparently rescued but after almost three weeks no punishment had been inflicted. A Serious Incident of Judge-Beating Occurs in Xiangfan City, Fazhi ribao (Legal System Daily), Aug. 17. 1988, at 1. (I am indebted to Professor Donald C. Clarke of the University of Washington for this citation.) 
[Vol. 52: No. 3

That is the wildest of conjectures of course. No one knows what is going to happen when Deng Xiaoping dies. It is generally assumed that there will be upheavals, but the ultimate form China will take remains a mystery. The future of obligation law is quite as uncertain as everything else, but it is difficult to be very hopeful about it. 


\section{APPENDix}

Provisions for Contracts of Hire-Processing (Promulgated by the State Council on Feb. 20, 1984, Bulletin of the State Council, No. 453, Jan. 20, 1985, at 5).

\section{Part I. General Provisions}

1. These provisions are issued according to the relevant rules of the Economic Contract Law of the People's Republic of China.

2. In a contract of hire-processing, the contractor completes a work according to requirements and specifications of the one commissioning it. The one commissioning receives the results of the work of the contractor and pays him the agreed-upon fee.

3. These provisions are used for contracts between juristic persons for processing, constructing to order, renovation, repair, printing, advertising, surveying, testing, etc. Contracts between independently managed households, agricultural village communes, specialized households, and keypoint households [on the one hand] and juristic persons [on the other hand] must be established in accordance with these provisions.

\section{Part II. Formation and Performance of Contracts}

4. When a contract of hire-processing is formed, the commissioning party must unequivocally proffer the specified article or items of the number, quality, and other special characteristics required. The contractor must supply equipment capable of performing the work, and technological conditions and a technological level precisely as required by the contract.

5. A contract of hire-processing must have the following provisions:

1. The name of the item to be processed or the work [e.g., advertising] to be done.

2. The quantity, quality, packing, and method of processing.

3. The [method of] supply of raw materials and specifications of quantity and quality.

4. Price or fee.

5. Time, place, and manner of performance.

6. The standard and method of performance.

7. The method of settling accounts, the bank in which the account will be kept, and the account number.

8. Penalty for breach of contract. [Literally, liability for breach of contract-but what is meant is a penalty even if there are no damages.]

9. Other provisions agreed on by the parties. Related written agreements on the technology involved, technological data, papers [e.g., blueprints], etc., are also component parts of the agreement.

6. The quality and technological standard of the object [of the contract], or the type of the work, will be discussed and agreed upon by the parties. The standard, code name, serial number, and the name of the standard must be clearly written and provided in the contract. The parties may not sign a contract without a quality requirement and a technological standard.

7. If the thing that is commissioned to be processed is an item that must be sealed up, it must be sealed and signed in the presence of representatives of the two parties and moreover looked after carefully and serve as evidence of its inspection and acceptance. 
8. The price or fee will be set in accordance with the rules of the state or the supervising ministry. When no price is decreed, one will be discussed and set by the parties.

9. According to related state rules, the one commissioning the work may pay earnest money to the contractor. The amount of the earnest money will be negotiated and set by the parties. If the one commissioning the work does not perform, he has no right to demand return of the earnest money. If the contractor does not perform the contract, he must return double the earnest money.

10. Subject to relevant state rules, when the parties have agreed, the one commissioning may pay the contractor in advance. If the one commissioned does not perform the contract, then, unless it has violated the agreement, it must return the amount of the advance payment. When the one commissioning the work does not perform the contract, he may set off the damages against the advance payment. If there is any surplus, he may demand its return.

11. If the materials of the contractor are used to complete the work, the contractor must select and use the materials specified by the contract. Moreover, he will allow inspections by the one commissioning. If the contractor hides a defect in raw materials or causes raw materials to be used that are not in accordance with the provisions of the contract and this affects the quality of the commissioned article, the one commissioning has the right to demand that [the work] be done again or repaired and that the price be reduced or refunded.

12. When the raw materials of the one commissioning are being used, the contract must clearly provide the quantity of materials to be consumed. The one commissioning must furnish materials according to the quantity, quality, and specifications provided in the contract. The contractor must immediately, according to the provisions of the contract, inspect the materials furnished by the one commissioning. If they are not in accordance with the contract, it must immediately notify the contractor to exchange or make up the deficiency. The contractor may not, on its own, without authorization, make substitution for the materials furnished by the one commissioning, nor may it stealthily exchange a part in an item that is to be repaired.

13. The contractor must, in accordance with the provisions of the contract, complete the work in accordance with the technological conditions desired by the one commissioning. It may not change them on its own without the consent of the one commissioning. The contractor shall be responsible for the quality of the entire work commissioned.

14. If, while the contractor is carrying on the work in accordance with the requirements of the one commissioning, it is discovered that the plans or technological requirements are not reasonable, it must immediately notify the commissioning party. The commissioning party must reply within the time provided [in the contract] and make suggestions as to changes. If the contractor has not received a reply within the designated time, it has the right 
to halt the work. It will notify the commissioning party. If, as a result, there is injury, it must be compensated for by the commissioning party.

15. If the commissioning party requires secrecy in connection with the commissioned work, the contractor must strictly observe [this requirement]. It may not, without the permission of the commissioning party, keep technical materials or duplicates.

16. While the work is going on, the contractor must permit inspection by the commissioning party. However, the commissioning party may not, in consequence, interfere with or hinder the usual work of the contractor.

17. When, in the inspection of the quality of the commissioned items and work concerned, there are differences of opinion between the parties, both parties may offer proofs of inspection by the legally designated quality control inspection organization.

18. The time for transferring (furnishing) the thing to be worked on must be in accordance with the time for [performance] provided in the contract. If either party demands that the time for delivery (furnishing) of the work be advanced or delayed, there must first be agreement with the other party, and this agreement will be carried out.

19. In calculating the time for sending (tendering) commissioned things, if the contractor uses its own means of transportation to send the thing, the time is computed from the day when the commissioning party seals the statement of its receipt. When a carrier is appointed to ship, the day when the carrier signs and seals receipt of the commissioned thing is the date for computing [times]. If [the one commissioning] itself picks up the item, the day [for computation] is the day when the commissioning party is given notice to pick up, but when the contractor gives notice to pick it up, it must give to the commissioning party the time required for the pick-up. If the parties have agreed otherwise, the computation will be in accordance with the agreement.

In computation of the time of delivery (furnishing) of raw materials and other things, the above provisions will be applied.

20. The commissioning party must inspect and accept the commissioned work that is completed by the contractor within the time provided in the contract. Prior to the inspection, the contractor must furnish the commissioning party with the necessary technical materials and related certificates of quality.

When quality defects in the commissioned work or object appear after a brief inspection, both parties must discuss the matter within the warranty period provided in the contract. Quality defects that appear within the warranty period must be repaired or replaced by the contractor except where they are the result of improper use of care by the commissioning party.

\section{Part III. Liability for Violation of The Contract}

\section{The Contractor's Violation of the Contract}

1. When the commissioned thing or completed work is delivered and is not in accordance with the provisions of the contract, if the commissioning party agrees to use it, the price must be adjusted according to the [reduced] quality. If [the 
commissioning party] does not agree to use it, the contractor must be responsible to repair or replace it. Moreover, it is liable for delays in delivery. If, after the repair or replacement, [the item] still does not meet the provisions of the contract, the commissioning party has the right to cancel acceptance. The contractor is liable to compensate for any resulting injury.

2. If the quantity of the commissioned objects or the completed work is less than provided by the contract, and the commissioning party still needs it, it [the contractor] must supply the deficiency in accordance with the [agreed-upon] quantity. The supplementary portion will be handled in accordance with [the provisions for] delayed delivery. If the part that is short is not needed by the commissioning party, the contractor is liable to compensate for any resulting injuries.

3. When the commissioned work is not packed in accordance with the provisions of the contract, the packing must be repaired or redone. The [contractor] is liable for the repair or redoing of the packing. Moreover, it is liable for any resulting expenses that were paid. If the commissioning party does not need repair of the packing or repacking, but demands compensation for injury, the contractor party must pay to the commissioning party the value by which the sub-standard packing that was used is less than the standard packing. The contractor is liable to pay damages for any injury or loss that is occasioned by failure to comply with the provisions of the contract.

4. In the case of an overdue delivery of the commissioned work, the penalty for breach of contract provided in the contract must be paid to the commissioning party. If the contract has no concrete provision, reference must be made to the provisions of the People's Bank of China on delayed payments. Calculate the damages on the basis of the relation of the delayed portion to the value of the whole and pay [that] to the commissioning party. In the case of work for which a fee is charged, for each day, pay damages for breach of contract of $1 / 1000$ of the total of the total value of the delayed portion of the work.

If the commissioning party does not agree, it has the right to refuse to accept commissioned work that is delivered in advance.

5. When the commissioned work or thing cannot be delivered, [the contractor] must pay 10-20 percent of the total of the [price] for the undelivered portion of the commissioned work that could not be sent or the work that could not be completed, or contract damages of 20-60 percent of the fee for that portion of work that could not be finished.

6. When a commissioned article is delivered to a different place, and is not in accord with the provisions of the contract, and it is put in temporary custody by the one commissioning, [the contractor] must pay the one commissioning the actual expenses of storage and maintenance.

7. If, in transporting or shipping the commissioned work it goes to the wrong destination or unit (person), except where the contract provides for responsibility for delivery to a specified place or receiving unit (person), [the contractor] is liable for the consequent increase in expenses of shipment and for the expenses occasioned by delay in shipment of the commissioned work.

8. When, owing to improper safekeeping, the raw materials, equipment, packing materials, and other articles provided by the commissioning party are injured or lost, [the contractor] must pay for losses thereby suffered by the commissioning party.

9. If the raw materials furnished by the commissioning party are not inspected in accordance with the methods or within the time provided by the contract, if it appears on inspection that these materials are not in accord with the contract and the commissioning party is not notified to change or to make up the delivery in accordance with the time period of the contract then the contractor is liable for the quality and quantity of the work.

10. If, without authorization, on its own, [the contractor] exchanges raw materials furnished by the commissioning party or a part of the article that was to be repaired that was furnished by the commissioning party, the commissioning party has the right to refuse acceptance. The contractor must pay damages for injuries suffered by the commissioning party in consequence. If the commissioning party demands that the work be done again or repaired again, [the contractor] must act in accordance with the commissioning party's demand. Moreover, it is responsible for overdue delivery. 


\section{The Liability of the Commissioning Party for Breach of Contract}

1. [The commissioning party] must compensate the contractor for any losses resulting from changes in the quantity, specifications, quality, or design made during the course [of the performance of the contract].

2. If [the commissioning party] cancels the contract in the course of performance, it will pay the contractor $10-30$ percent of the value of the unperformed portion of the contract, as well as damages for raw materials that belong to the contractor. It will pay, as breach of contract damages, 20-60 percent of the fee for the unperformed portion of the contract for goods that do not belong to the contractor.

3. If it tenders raw materials or technical materials or packing materials that are not in accordance with the terms of the contract, or does not complete the necessary assistance and preparatory work, the commissioned party has the right to cancel the contract. The commissioning party must pay damages that are thereby incurred. If the contractor does not demand the cancellation of the contract, then apart from the postponement of delivery of the commissioned work, the commissioning party must pay compensatory damages for the losses from stopping work and waiting for materials.

4. When it exceeds the time provided in the contract for receiving the commissioned work/thing, then, apart from the breach of contract damages provided in section 5 of these regulations, it must also be liable/responsible for the actual expenses incurred by the contractor in storage and maintenance. If the commissioned party does not take delivery of the commissioned work for six months after the time for receipt, the contractor has the right to sell the commissioned thing. After deducting from the price the fee and the expenses of storage and maintenance, the price received will be returned to the commissioning party. If the price received from the commissioned work is less than the fee and the amounts expended on storage and maintenance, the commissioning party must pay the amount by which it is insufficient. It must pay damages for any loss suffered by the commissioned party.

5. If [the commissioning party] delays in paying the contract price beyond the contract time, it must pay damages for breach of contract to the commissioned party by reference to the rules of the People's Bank of China for delays in payment. Taking the fee as the basis of computation, $1 / 1000$ of the total fee will be damages for each day of delay.

6. If, without cause, it refuses to accept the commissioned work, it must pay the contractor any losses it suffers, as well as a fine to the transportation office.

7. If it changes the place of delivery or of the receiving unit (person) it is liable for any increased expenses this may cause.

23. If, within the time for performance provided by the contract, the commissioned work or raw materials are injured by unavoidable force, after the contractor has obtained proof, it may avoid responsibility for breach of contract. But it must take active measures to reduce harm to the maximum extent possible. If this happens outside the time provided in the contract, it may not avoid responsibility. [If it happens] while the commissioning party is in delay, or has refused acceptance without a cause, the commissioning party must bear responsibility. Moreover, it must compensate the contractor for any injuries suffered thereby. 
